International Journal of English Literature and Social Sciences
Vol-6, Issue-3; May-Jun, 2021

Peer-Reviewed Journal

\title{
The Image of the Gulf Cooperation Council Countries Among the Iraqi Academic Elite After the Qatari Crisis
}

\author{
Assist. Prof. Dr. Ethar Tareq Khaleel
}

Al-Iraqia University, College of Media, Iraq

Received: 24 April 2021; Received in revised form: 14 May 2021; Accepted: 25 May 2021; Available online: 02 Jun 2021

C2021 The Author(s). Published by Infogain Publication. This is an open access article under the CC BY license

(https://creativecommons.org/licenses/by/4.0/).

\begin{abstract}
The Gulf crisis constituted a major and fundamental turning point in the history of the Arab region due to the resulting data that changed the course of Arab-Arab relations on the one hand and Arab regional relations on the other. If the Arab citizen has become accustomed to a stereotyped image through which he sees the Gulf relations as an integrative relationship based on the strength of the economy and the unity of politics, then the Gulf crisis has revealed a new image of that atypical relationship that has gone beyond the limits of the problem to form a crisis. Consequently, the Gulf states have been made a test of the consequences of this crisis on the region and its peoples, especially since the Gulf Cooperation Council states have been divided into two groups, one team siding with the Kingdom of Saudi Arabia against the State of Qatar, and another group taking a position of neutrality.
\end{abstract}

This paper deals with the nature of that crisis and how the crisis was managed for both parties, leading to a set of results reached by the research, the most important of which are:

1- The results of the study also reflected a negative view of the possibility of the GCC countries to overcome their differences soon, and this is reinforced by their vision that is compatible with the incompatibility of the Qatari political vision with the rest of the GCC countries.

2- There is a negative mental image among the academic elite about the role played by the Gulf Cooperation Council countries towards the unity of Iraq, and the possibility of accepting it as a new member added to the GCC countries. Iraq to Kuwait in 1990.

3- There is a mental image of the academic elite that sees that the crisis between the two parties is more political than media, but its causes do not rise to the level of intellectual, religious or economic disputes or crises, which are usually characterized by depth and strong influence and repercussions.

Keywords-Mental image, GCC, academic elite and crises.

\section{INTRODUCTION}

The crisis that erupted between the parties of the Gulf Cooperation Council constituted a point of challenge in the Council's march, which the masses used to find harmonious and understanding and possessing decisions, positions and unified visions regarding the events they are facing.

Since the Gulf dispute has become a reality, this leads to a search for its causes and repercussions on the GCC states

IJELS-2021, 6(3), (ISSN: 2456-7620) on the one hand, and the countries of the region, as they are the most affected by it.

This will also lead to an examination of the repercussions of this crisis on the image of the GCC states among the academic elite in general, as long as the other had formed a certain image over a period extending from the date of the announcement of the formation of the Council in 1981 until now. 
And here it is worth answering the questions of the research problem about the level of influence of the Council's image and how the academic elite, especially those interacting with the event, view this difference and disparity among the GCC states, which in turn constituted a crisis reality.

Was this image subjected to a change or distortion among the elite, and what is the level of this change, if any? What are the areas of the crisis and its temporal, spatial and human limits? The Council is located within an Arab and international environment that affects and is affected by it.

The research included three sections. The first topic dealt with the methodological framework of the research, diagnosing the research problem, posing a set of questions to answer, the importance of the research to serve the topic, audiences and the scientific library, and the research objectives, which were identified by a set of points that stemmed from the questions raised by the research problem and the selection of the community, sample and approach. Consistent with the nature of the research and its various fields, leading to a review of previous studies.

The second topic dealt with the theoretical framework of the research, which includes the research literature supported by scientific sources for the main research variables, in a careful and realistic reading of the concepts of the mental image and the crisis, and a historical look at the reasons and justifications that led to the crystallization of the idea of the emergence of the largest Gulf grouping represented by the Gulf Cooperation Council countries.

In the third topic, the researcher dealt with the practical framework of the research, which is a reading of the respondents' answers to the research tool "the scale", which was prepared with the aim of measuring the reality of the picture for the GCC countries, especially after the emergence of the Qatari crisis.

1.1 The importance of the research: The research gains its importance from the nature of the topic it deals with, as it is one of the topics that are directly related to the reality of the Arab region and its regional surroundings, as it discusses an issue that has repercussions that may affect the entire region due to the importance of the Council.

The importance of the research lies in the fact that it provides a reliable scientific reference in the scientific library, which contributes to assisting researchers as well as the concerned institutions in benefiting from its results.
What is the image of the Gulf Cooperation Council countries for the Iraqi academic elite after the Qatar crisis?

1.2 The research problem: With the aim of clarifying the nature of the mental image of the Iraqi academic elite about the Gulf Cooperation Council countries after the Qatari crisis, the research problem was formulated by asking a main question that included a number of subscientific questions that can then be answered by the respondents to clarify the features of this picture Its three dimensions which are cognitive, behavioral and emotional.

From this main question, the following sub-questions emerged:

1- What are the causes of the Qatari crisis according to the vision of the Iraqi academic elite?

2- What are the resources that the Iraqi academic elite derive their information about the crisis?

3- What is the vision of the academic elite for the future of this crisis on the GCC countries?

4- What are the repercussions of the Qatari crisis on the GCC countries and the region in general?

5- Has the image of the Gulf Cooperation Council countries changed among the Iraqi academic elite after the Qatari crisis?

1.3 Research Objectives: Since the scientific research activity is an organized and purposeful scientific activity, the researcher must specify the objectives that he/sheintends to reach in his research, so this research aims to reach the following objectives:

1- Identifying the nature of the mental image of the Gulf Cooperation Council countries after the Qatari crisis.

2- Access to the causes of the Qatari crisis according to the vision of the Iraqi academic elite.

3- Identifying the parties from which the respondents derive their information about the Qatari crisis.

4- Getting to know the future of the Qatari crisis on the GCC countries in the eyes of the Iraqi academic elite.

5- Knowing the repercussions of the Qatari crisis on the GCC countries and the region in the eyes of the Iraqi academic elite.

6- To identify any possible changes to the image of the GCC states among the Iraqi academic elite.

1.4 Research Methodology: The survey method has been used in the context of the research, as it is one of the methods used in media studies, and this is consistent with the nature of the research, and because the study was descriptive, it was not limited to describing the 
phenomenon only, but rather delving into its depths with the intention of highlighting the constituent and controlling variables.

1.5 The research community and the sample: The research community is represented by the Iraqi academic elite that represents university professors, being one of the types of elites in general, which is the vanguard responsible for the basic changes that occur in society as the main tool for its transition from one level to a better level, and this cannot be happened. So, The entire society had to choose a representative sample for the researcher. Professors of the faculties of media and political sciences in the universities of Baghdad and Al-Iraqiya have been chosen, as they are the most interested in the processes of news transmission and current events, their analysis, interpretation and presentation to the general public.

Two Hundreds forms were distributed, of which (184) were correct, while (16) were neglected due to their invalidity.

1.6 Research fields: When studying cases and phenomena, it should be taken into account to identify them in three areas, which are as follows:

1- The human domain: the human domain is represented in the Iraqi academic elite, who are professors of Iraqi universities who hold academic titles in those specializations such as assistant lecturers, lecturers, assistant professors and professors.

2- Temporal domain: The temporal domain of the research extends to the period following the Qatari crisis with the countries of the Gulf Cooperation Council, which is the period during which the research was conducted and the preparation and distribution of the mental image scale on the research sample, collecting it, analyzing its data, and extracting its results according to the respondents' answers.

3- The spatial domain: It was specified in the faculties of media and political science within the universities of Baghdad and the Iraqiya.

1.7 Research tools: The scale has been used as a tool to obtain data from the respondents, and it came in five paragraphs, according to the Likerd scale (strongly agree / agree / neutral / disagree / strongly disagree), and thirtyeight phrases were formulated according to the three dimensions that make up the mental image which are the cognitive dimension, behavioral dimension and emotional dimension.

In order to reach an accurate scientific analysis process, statistical program (SPSS)has been used, as the data was entered into the program. Therefore, a number of statistical operations have been conducted such as chi- square, arithmetic mean, standard deviation, percentage and repetitions for each of the expressions.

\section{THEORETICAL FRAMEWORK}

\subsection{A brief history of the establishment of the Gulf Cooperation Council}

Barghash (2015) believes that the idea of establishing the Gulf Cooperation Council began after the British withdrawal from the Gulf in 1968 on the basis of a fusion political union between the Gulf states, with the aim of achieving cooperation in all political, economic and military fields and creating a kind of unity and union on strong and solid foundations for the peoples of this region and its stability. (p.7)

The spark of the war that erupted between Iran and Iraq in 1980 was an important reason for the establishment of the Gulf Cooperation Council, especially Marhoon (1997) thinks that "the rise of the six Gulf states had become afraid of the possibility of this war spreading to their territories, which accelerated the intention of those countries to unite to ward off that danger."(p.112).

If that war could be one of the influences in the region and in the nature of the historical relationship between its states, especially with those that overlook the Arabian Gulf basin, but it is not organized under the banner of the Council, such as Iraq and Yemen, for example, the political crisis caused by Iraq's entry into the State of Kuwait and what It was followed by repercussions up to the year 2003, as well as the economic and geopolitical aspects that formed all elements to strengthen the bonds of power and cohesion between the GCC countries, to ward off any threat that might face one or all of their countries.

Al-Shammari (2012) identifies a number of facts on which the establishment of the Council was based, namely:

1- There is not a single Arab country that can provide it with security on its own and in isolation from Arab national security.

2- Development cannot be achieved within the framework of a small closed entity, given that development issues that are national in their comprehensive sense.

3- Regional groupings have become a feature of the times and in light of the Arab state of Qatar, and in the context of searching for a formula for compatibility between Qatari peculiarity and the inevitability of grouping, the Gulf Cooperation Council becomes a logical formula for regional grouping between countries that have the 
features and specificity that make it an integrated entity.(p.7)

However, the repercussions of the Qatari crisis are now threatening the unity of this council, which has been lined up by a united state for nearly thirty-six years. Except for returning this country to the family of the Council, as belonging to the Council entails commitments to its charters and principles, and the State of Qatar has departed from its obligations to it.

Some explain this crisis within a historical background linked to the coup of 1995, and before and after it a number of incidents and situations that contributed to the tension in the relationship between the GCC states. In fact, Meguid (2008) believes that "many crises begin as an issue but develop into a crisis as a result of the administration's neglect of it in its early beginning or as a result of the occurrence of a specific event that led to the crisis."(p.85)

Idris (2000) thinks that "the relations between the GCC states witnessed different types of interactions that were a mixture of cooperation and conflict, and in the estimation of some, they witnessed only limited opportunities to transform into a bloc at the collective level, and it did not reach the institutional level that qualifies it to acquire the necessary effectiveness that enables it to reach relations between states members to the desired level of conglomeration or amalgamation."

Disagreements escalated between a number of Gulf Arab states and Qatar and reached their climax in 2013, and Qatari policies in the estimation of some of the Gulf Cooperation Council countries have become a source of danger to their security, which led to some GCC countries cutting their diplomatic relationship with the State of Qatar, and this lasted for eight months. Until 2014, the Riyadh Agreement was reached between the Custodian of the Two Holy Mosques King Abdullah, may God have mercy on him, and Sheikh Tamim bin Hamad Al Thani, Emir of the State of Qatar, which includes consensus on six issues, namely:

First: Not to interfere directly or indirectly in the internal affairs of any of the GCC states.

Second: Not to harbor or naturalize any of the citizens of the Council who have an activity that contradicts the regulations of any state, except in the event of its approval, and not to support groups opposed to their states.

Third: Not supporting the hostile media.

Fourth: Not to support the Brotherhood Party or any of the organizations, or individuals that threaten the security

IJELS-2021, 6(3), (ISSN: 2456-7620)

https://dx.doi.org/10.22161/ijels.63.61 and stability of the GCC states through direct security action or by attempting political influence.

Fifth: None of the GCC countries provide support to any group in Yemen who poses a threat to Yemen's neighboring countries.

Sixth: Not to violate the policy approach of the Gulf Cooperation Council countries towards supporting Egypt, contributing to its security and stability, contributing to its economic support, and stopping all media activities directed against it in all media, directly or indirectly.

However, some of the GCC states believe that Qatar has not implemented these commitments, and a number of accusations have been leveled against it that Qatar's role in the Yemeni crisis was a dual role in the interest of the parties hostile to the "Decisive Storm" alliance, which led to the termination of Qatar's mission in this alliance, especially since it had concluded Defense Cooperation Document with Iran. In February 2010, it turned into a framework of "military cooperation" later, and these countries made several accusations supported by arguments, facts and evidence, based on the fact that four years of concluding the agreement were enough to show goodwill between the various parties, especially to the State of Qatar, which is accused of. Diplomatic relations were severed with it, then an air, land and sea boycott took place, which Qatar interpreted as a siege, while the boycotting countries interpreted it as only a boycott and does not fall within the concept of economic blockade, and the crisis situations between the two parties did not subside until the beginning of 2018.

Although crises are a human phenomenon that can occur at all times, the repercussions of any crisis can have a negative impact on any individual, institution, society or state, which requires working to manage it in a way that leads to reducing its risks and repercussions on the situation. Whoever employs it in a way that achieves the maximum benefit to his institution. Therefore, Bland (1998) defines it as "any abnormal event that attracts the attention of the media and that the crisis is often sudden and unexpected, as it can be opportunities as much as it carries problems."(p.5)

Al-Alkim (2000) thinks that a distinction must be made between crisis and crisis management, for the crisis is defined as a critical and decisive moment related to the fate of the political or administrative entity that has been affected by it, thus creating a severe difficulty or a challenge for the decision maker, making him extremely confused as to how to deal with the unstable reality.(p.3)

Hawash (1998) also defines it as "a turning point or a sudden situation that leads to unstable conditions, which threatens national interests and the infrastructure, and 
causes undesirable results, all in a short time that requires a specific decision to confront at a time when the concerned agencies are unwilling or unable to make confrontation".(p.270)

Reveret and Moreau (1997) also define it as "it changes all the variables of the physical and human environment, in such a way that references become non-existent and individuals do not know how to act".(p.31). While Barton (1993) believes that it is "a large, unpredictable event that may have negative consequences."(p.72)

Eleiwa (2003) thinks that crisis management means how to overcome crises with various scientific and administrative tools, avoid their negatives and take advantage of their positives, the science of crisis management is the science of managing balances, monitoring centers and trends of power, adapting to different variables, and examining their effects in all fields. (p.80). Moreover, Jamal (2010) defines Crisis management as how to deal with crises using modern scientific methods, means and strategies to prepare for the problems that threaten the reputation of the institution by taking quick, decisive and accurate decisions to prevent the occurrence of the crisis and reduce the size of material and human losses in the event of their occurrence to the maximum extent possible. (p.30). Therefore, it must be dealt with in deliberate and planned ways and the formation of a team to manage it before it occurs.

However, Robert and John (1983) think that "the team works as an integrated and interconnected unit that has one specific goal, which is to deal with the crisis, and to prevent its escalation, and to preserve the administrative entity and its ability to continue and withstand the events of the crisis." (p.70).

According to Mitsoff and Amagos (2001) "there is a media dealing with the crisis, such as appointing an official spokesperson for the crisis management team so that there is no conflict in statements and the establishment of a communications center to respond to inquiries related to the crisis and take it upon itself to take into account the quality of the image format transferred from the site of the event in proportion to the data of the crisis and so that there is no conflict between the images and the data, which can cause confusion among the masses (p.41).

This crisis reality naturally imposes its effects on the image of any institution, whatever its size and whatever its image among its internal and external audiences. crisis and public interest, the line between the two blurs, blend together.

\subsection{The mental image: a conceptual reading}

The use of the concept of mental image dates back to the American scientist Walter Lippmann in his book The Public Opinion in 1922, when he indicated that the individual learns to see with his mind the world that he has not seen, touched, smelled or remembered and thus gradually creates a trustworthy image for himselfinside his mind for the world he didn't touch. (Ajwa,1983,p.3)

The mental image of the public varies from one individual to another, according to his interaction with the environment to where he belongs, so it is possible to find that the image is not the same, because the interaction and experiences are different between them, and from this factor, the individual may share and explain his experience in the light of those experiences that he acquires in the course of his life. Therefore, it is considered a special subjective mental process and it may dominate the eyes and minds of people and play a major role in influencing and persuading. It is an assumed interpretation of the reality that the individual lives in, and based on this subjectivity, a non-neutral image may form and do not reflect the whole truth, but rather it may be distorted or deformed. It is somehow possible to find this represented in the definition formulated by Hanan Youssef for the concept of the mental image as "A simplified representation of an unreal environment, and this representation results from the limited time that man possesses in this life on the one hand, and the limited opportunity available to him for direct personal identification to the realities of the world around him on the other hand." (Al-Sharqawi and Al-Qalini,2003,p.13)

A fragmented concept of mental image emerged from many scholars such as Jeffkins, who thinks that the concept of mental image means correct impression.In fact it is the impression that individuals have, regardless of whether it is true or false. An inaccurate image, as well as affected by emotions that can add another dimension to the vision of reality, the information is perceived in a manner consistent with the truth by the influence of the preparations of individuals and trends related to what is perceived.

In sum, the mental image represents a part of the overall reality, and therefore, any message that includes certain information about a subject represents only a part of the comprehensive information on this subject, so the party responsible for building the mental image resorts to choosing parts of this image.

The mental image is defined as the sum of all the impressions formed by the public's awareness of a person or an institution, and this image is not imprinted, and acquired once, but it is an advanced process, and is formed continuously in the awareness and feeling of 
individuals; It is the final product of the subjective impressions formed by individuals or groups, based on the experience available to them about a particular person, system, state, facility or organization that can have an impact on human life through direct or indirect contact with it.

It also can be defined as the final product of the subjective impressions formed by individuals or groups about a particular person, a regime, a particular people, a race, a local or international organization, or anything else that can have an impact on a person's life. These impressions are formed through direct or indirect experiences, and these experiences are related to the emotions and beliefs of individuals regardless of the validity or incorrectness of the information contained in the summary of these experiences.

Hence, it is possible to find that the mental image will be subject to change if new information about the institution is added to it, and as a result of this new information, the individual or society will have revisions that may be minor or may be a complete rebuilding of the image. However, the relative dynamics in the reality of the image, the mentality can present the concept of a stereotype, which is usually characterized by rigidity, difficulty in changing, and negative in most of its orientations, and the perception of the people is a unified or similar perception for all its members, and Liebmann expresses that.

It is like drawings inside
our souls that are
difficult to modify". This
is simply because the
stereotyped image part of
the mental image, this
does not mean that every
image, or that every
mental image is a
stereotype, as the
concept of mental image
is broader and more
comprehensive.

(Al-Shatri,2003,p.118)

Therefore, some scholars tended to differentiate between the two images mental and stereotyped, and although they differed in determining the places of difference, it can sum up in six main points, namely:

1- The mental image is based on objective facts and truthful information, while the stereotyped image is based on exaggerated facts and distorted information.
2- The mental image is not necessarily emotionally charged, unlike the stereotyped image that is loaded with subjective feelings and charged with personal emotions.

3- The more information in the mental image increases its clarity, while the increase in information in the stereotyped image in the direction of the same subject leads to intolerance and in stages that lead to racial discrimination.

4- The mental image makers of things, people, states and groups in the minds of individuals seek to present information, facts and knowledge in order to expand people's perceptions and knowledge of life, in contrast to the stereotypical image that often stands behind parties with political, social or economic interests.

As some see that the difference between the two images lies in two main points, namely:

1- The mental image can be changed as it is characterized by relative stability, while the stereotyped image resists change and is difficult to change.

2- The stereotype image is mostly negative and biased, in contrast to the mental image that is positive and in other negative circumstances.

\subsubsection{Stages of mental image formation:}

The mental image passes through a number of stages through which it is formed, and these stages are connected to each other until the image reaches the stage of stability. These stages are represented by several points, namely:

1- The stage of homogeneity of the mental image: It is the stage in which the image is gradually interconnected, and its characteristics are consistent and the individual has an appropriate assessment of things regarding the subject of building the image.

2- The stage of polarizing the mental image: This stage is characterized by the image owner's adherence to the features that he adopts greatly, and his belief in their truthfulness. So, the negative impact of the mental image begins to appear.

3- The stage of stabilization of the mental image: This stage comes after the stability of the homogeneous and polarized image for a long period of time, which leads to it reaching the stage of stability, and the mental image gains the ability to change.

However, despite the relative stability that characterizes the mental image, it is capable of movement and modification in light of the feelings and behaviors that come out, and this is consistent with the process of interaction with the environment. 
The process of forming the image of the individual depends on the following:

1- Direct experience: By dealing with the person or entity from which the image is formed, given that the daily interaction of the individual with other individuals, institutions, companies, regulations and laws is a direct and influential source for forming self-impressions about a person, organization or country.

2- Indirect experience: It is what a person or entity derives from ideas, visions and perceptions about a company, an entity, an individual, or a people through the media, considering that these media are among the most important institutions that create images through their communicative activities represented in publishing information, news, images, graphics and analysis.

\subsubsection{Features of a mental image:}

The mental image has a set of features and characteristics that can be summarized as follows:

1 - It is not just a simulation but a framework for memory and a process of constructing perceptions.

2- The image may be characterized by clarity, ambiguity, truth or lack of truth.

3- It is characterized by generality and privacy according to the extent to which others participate in this image, i.e. it is something specific to the individual alone, as the public resorts to generalizing about the mental images that are formed about the social reality, and does not necessarily focus on the details of these images to the extent that the generalization may reach a disturbing simplification.

4- Consciousness and sub-consciousness. The public cannot perceive all parts of the image at the same time and with the same intensity.

5- The image is a summation of all previous experiences of the individual.

6- It is characterized by flexibility and continuous interaction, so it develops, grows, expands and accepts change throughout life.

7- It is the product of the interaction of the elements of knowledge and perception, and the social and historical context influences the formation of different mental images.

The context of the high level of interest in the concept of mental image and the intensity of studies that were concerned with it by scholars, and after it gained the attention of business companies and institutions that seek to crystallize positive impressions of them among the masses they deal with, the interest of countries in this concept increased and began to pay attention to their image among their audiences first and the other in a general way, especially those countries whose image has been distorted or deformed as a result of counteroperations practised against them by other countries as a result of their different orientations and interests.Or through the mistakes that faced their path, such as their entering into internal and external conflicts or as a result of their carrying out hostile acts and other foreshadowings that in turn contribute to creating the impression and the formation of the image. Therefore, a new concept has crystallized in the field of mental image studies, which is called the national image, which can be objective influenced by fanatical ideas characterized by simplification in their view of the other.

It is a common belief that the image of a state or a group of states that has a set of common characteristics also affects the behavior of the international community towards this state, and therefore every state is keen to observe the international community in an image that serves its goals and makes every effort to convince others of the sincerity of the image, and it offers all its capabilities to remove any negative aspects or features in its current image and to avoid any unwanted changes that may occur to this image.

Some scholars classify the mental image that the public holds towards the organization into several types, the most important of which are:

1- The mirror image: It is the image that the organization observes that the public carries about it, and it sees itself through it, and it may be completely different from what the officials in the organization think, due to the lack of knowledge about the public's attitudes towards the organization.

2- The current image: It is the image that the public holds towards the organization, which can be based on experience and good knowledge of the organization, or it can be based on distorted information or few and incorrect data about the organization.

3- The desired image: It is also called the desired image, and it is the image that the organization desires to form in itself in the minds of the masses, and it is often new and unknown impressions to the public that the organization seeks to create.

4- The ideal image: It is the best image that the public can carry towards the organization, taking into consideration the competition between the different organizations, which are trying to influence the masses.

5- The multiple image: It is formed when the crowd is exposed to two different models of the organization, each of which gives a different impression of it, and it is 
natural that this discrepancy in impressions does not continue, turning into negative or positive, or may combine the two depending on the severity of the impact of each on the members of the public.

\subsubsection{The significance of a mental image}

The significance of the mental image lies in its depiction of things about reality, which may be unreal or inaccurate, accompanied by feeling that the resulting impression towards subjects, personalities and states is unreal, while they only represent mental images that can be created, and therefore the reality is not the mental image. The mental image is not a reflection of the positive, and therefore each person has a mental image from which to judge things, people and states, and here comes the role of the media in shaping features of the mental image of the audience.

The importance of the mental image is also confirmed in that it plays an important role in the lives of individuals and states, as it is assumed that it forms in individuals images of dense things such as states or peoples and others, as well as the impact of the nature of the political system in which the individual lives within its orbit, and this is reflected in the general principles of the theory of power that sees the individual or the citizen is nothing but a follower who is unable to rely on himself.

The importance of studying the mental image of these countries comes from the fact that it provides the answer to three dimensions:

First, the cognitive dimension

Through which the individual can perceive a certain idea or impression related to some states, people or societies, such as his knowledge of the history and geography of this state, current information about it, and its most important features in all fields.

Second: the emotional dimension

This dimension is represented in the individual's feelings and emotions towards a state, positively or negatively, and in degrees determined based on the cognitive dimension in the base, in addition to life experiences, if any.

\section{Third: the procedural dimension}

This dimension refers to the extent of which the image of this state or people has penetrated the conscience of a someone to the extent that this person is ready to travel to this dreaming country and live in it permanently.

\subsection{The elite and its role in society}

The credit for inventing the theory of elite or the so-called elite. Karl Marx is the first to launch the term elite in reference to the ruling minority in which he emphasized the differentiation of individuals belonging to any field of social life.

The word elite is synonymous with the word influential, as the term elite is sometimes used as an alternative to the term influential, to denote the same group selected from the community. Ibn Manzur defined the elite in Lisan alArab Dictionary as derived from leaders, and he chose something in the sense that he chose it, and the elite of the people are their choice, and he chose the thing in the sense of choosing and extracting it.

The elite plays an important role by influencing the society to which it belongs, and sought to develop aspects of society at the social, economic and political levels, in order to achieve a state of progress and development that is directly reflected on the institutional performance of governments in their quest to adopt the ideas of the elite.

The concept of the elite is defined as a group of people who possess the highest levels in their own activities, and occupies a prominent place in society in relation to a particular activity, and it is also known as a group of educated and conscious members of public opinion characterized by knowledge, expertise and good behavior, as it leads public opinion. It is also defined as the people at the top of the social hierarchy, who control and manage institutions of higher education, the instruments of cultural production, and formulate the terminology for discussions of public events.

It also represents the concept of the elite as a group of individuals that directly influence decision-making centers, or indirectly through the formation of public opinion, and that the determinants of the elite are represented in an authoritarian position, wealth, or fame, which allows these individuals to contribute to decisionmaking. The elite also means that it is the link between those who are unable to express their opinions, and those who have decision-making, as it is the owner of guidance in decisions, and it is itself the pioneer in directing society towards progress. Certainly, with the change of societies, and the occurrence of revolutions or uprisings, the role of the elite often fluctuates, especially when the degree of societal awareness decreases, which distorts their image in front of the community, and as a consequence it becomes difficult for public opinion to align with their opinions.

The role of the elite is manifested in formulating basic concepts, establishing organizations, inventing and finding developmental means, creating and developing the necessary wealth, working to establish value systems, protecting and developing them, and developing society through social change. 
The elite in society may be academic, media, political or religious. In the past, education led to extracting the individual from the traditional roles that he used to play within the institution, where the educated person is distinguished from other people by his knowledge and religious discipline was dominant. So, he joins the educated elite, and science remained important for the individual to enter the educated elite and rise up the social hierarchy.

Also, this term is applied to many fields. So, it is possible to find a trusted elite, a military elite, a business elite, and others. One of these elites is a function in its field of existence, and within this vision it has become possible to talk about cultural, social and political elites working within the scope of civil society and in the cultural field without reaching power.

What is meant by the elite in the research is the academic elite, which represents part of the intellectual elite that includes writers, thinkers, university professors, scientists and philosophers, as well as one of the types of elite in general, which is the vanguard responsible for the fundamental changes that occur in society as the main tool for its transition from one level into a better level, it can give up its interests for a while and adhere to neutrality in the face of the public interest.

The academic elite is defined as the category that holds the highest academic qualifications, and the same distinguished position in society, with its awareness, culture and ability to influence public opinion, and form the values and culture of a large group of society by virtue of the nature of its teaching function for generations of students and students in universities, and through its publications of scientific and cultural participation.

2.3.1 The image of the Gulf Cooperation Council countries among the Iraqi academic elite after the Qatari crisis

Gender: male (108) female (76)

Length of service: Less than 10 years (46) 10-20 years (85) More than 20 years (53)

Academic title: Assistant teacher (42) teacher (50) assistant professor doctor (61) professor (31)

A table showing the respondents' answers to the questions the scale for the cognitive, behavioral and emotional dimensions

\begin{tabular}{|c|c|c|c|c|c|c|c|c|c|c|c|c|c|c|c|}
\hline $\begin{array}{l}\mathbf{N} \\
\mathbf{0}\end{array}$ & Cognitive Dimensions & $\begin{array}{l}\text { Stro } \\
\text { ngly } \\
\text { Agr } \\
\text { ee }\end{array}$ & $\begin{array}{l}\text { Perce } \\
\text { ntage }\end{array}$ & $\begin{array}{l}\text { Agr } \\
\text { ee }\end{array}$ & $\begin{array}{l}\text { Perc } \\
\text { enta } \\
\text { ge }\end{array}$ & $\begin{array}{l}\text { Neu } \\
\text { tral }\end{array}$ & $\begin{array}{l}\text { Perc } \\
\text { enta } \\
\text { ge }\end{array}$ & $\begin{array}{l}\text { Disag } \\
\text { ree }\end{array}$ & $\begin{array}{l}\text { Perc } \\
\text { enta } \\
\text { ge }\end{array}$ & $\begin{array}{l}\text { Stro } \\
\text { ngly } \\
\text { Disa } \\
\text { gree }\end{array}$ & $\begin{array}{l}\text { Perc } \\
\text { enta } \\
\text { ge }\end{array}$ & $\begin{array}{c}\text { Mea } \\
\mathbf{n}\end{array}$ & $\begin{array}{c}\text { The } \\
\text { Directio } \\
\text { n }\end{array}$ & $\begin{array}{l}\text { Devi } \\
\text { atio } \\
\text { n }\end{array}$ & $\begin{array}{c}\text { Chi } \\
\text { Squar } \\
\text { e }\end{array}$ \\
\hline 1 & $\begin{array}{l}\text { The unity of the Gulf } \\
\text { Cooperation Council } \\
\text { faces a fateful } \\
\text { challenge }\end{array}$ & 33 & $\% 18$ & 47 & $\% 26$ & 42 & $\% 23$ & 37 & $\% 20$ & 25 & $\% 14$ & 3,14 & Neutral & 1,31 & 18,38 \\
\hline 2 & $\begin{array}{l}\text { GCC countries are } \\
\text { not united on } \\
\text { regional issues }\end{array}$ & 47 & $\% 26$ & 41 & $\% 22$ & 33 & $\% 18$ & 34 & $\% 18$ & 29 & $\% 16$ & 3,13 & Neutral & 1,42 & 15,68 \\
\hline 3 & $\begin{array}{l}\text { The causes of the } \\
\text { Gulf dispute with } \\
\text { Qatar go back to the } \\
\text { (white coup) in } 1995\end{array}$ & 22 & $\% 12$ & 41 & $\% 22$ & 21 & $\% 11$ & 42 & $\% 23$ & 58 & $\% 32$ & 2,60 & $\begin{array}{c}\text { Disagre } \\
\mathrm{e}\end{array}$ & 1,43 & 41,28 \\
\hline 4 & $\begin{array}{l}\text { The crisis with Qatar } \\
\text { will affect in the } \\
\text { future the project of } \\
\text { political and } \\
\text { economic integration } \\
\text { of the GCC states }\end{array}$ & 38 & $\% 21$ & 51 & $\% 28$ & 19 & $\% 16$ & 50 & $\% 27$ & 26 & $\% 14$ & 3,14 & Neutral & 1,39 & 36,15 \\
\hline 5 & $\begin{array}{l}\text { I get my information } \\
\text { about the Gulf crisis } \\
\text { with Qatar from } \\
\text { social media }\end{array}$ & 40 & $\% 22$ & 52 & $\% 28$ & 31 & $\% 17$ & 31 & $\% 17$ & 30 & $\% 16$ & 3,22 & Neutral & 1,39 & 20,74 \\
\hline 6 & $\begin{array}{l}\text { I get my information } \\
\text { about the crisis from } \\
\text { TV }\end{array}$ & 37 & $\% 20$ & 50 & $\% 27$ & 54 & $\% 29$ & 22 & $\% 12$ & 21 & $\% 11$ & 3,33 & Neutral & 1,25 & 40,48 \\
\hline 7 & $\begin{array}{l}\text { I get my information } \\
\text { about the crisis from }\end{array}$ & 18 & $\% 15$ & 21 & $\% 11$ & 34 & $\% 18$ & 73 & $\% 40$ & 38 & $\% 21$ & 2,5 & Disagre & 1,22 & 73,72 \\
\hline
\end{tabular}




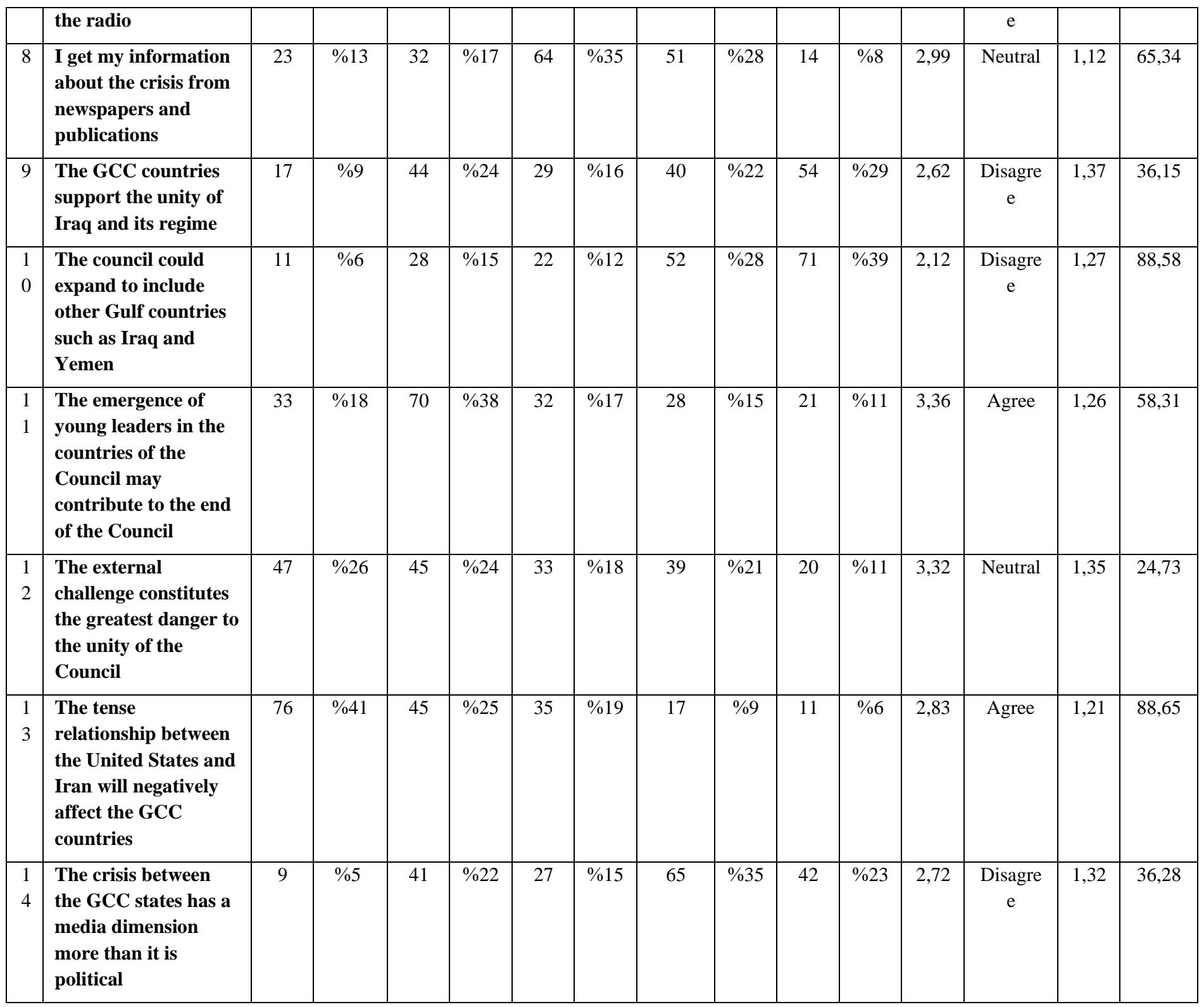

\begin{tabular}{|c|c|c|c|c|c|c|c|c|c|c|c|c|c|c|c|}
\hline $\mathbf{N}$ & $\begin{array}{l}\text { Behavioral } \\
\text { Dimensions }\end{array}$ & $\begin{array}{c}\text { Str } \\
\text { ong } \\
\text { ly } \\
\text { Agr } \\
\text { ee }\end{array}$ & $\begin{array}{c}\text { Per } \\
\text { cen } \\
\text { tag } \\
\text { e }\end{array}$ & $\begin{array}{c}\text { Agr } \\
\text { ee }\end{array}$ & $\begin{array}{c}\text { Per } \\
\text { cen } \\
\text { tag } \\
\text { e }\end{array}$ & $\begin{array}{l}\text { Neu } \\
\text { tral }\end{array}$ & $\begin{array}{c}\text { Per } \\
\text { cen } \\
\text { tag } \\
\text { e }\end{array}$ & $\begin{array}{l}\text { Dis } \\
\text { agr } \\
\text { ee }\end{array}$ & $\begin{array}{c}\text { Per } \\
\text { cen } \\
\text { tag } \\
\text { e }\end{array}$ & $\begin{array}{c}\text { Str } \\
\text { ong } \\
\text { ly } \\
\text { Dis } \\
\text { agr } \\
\text { ee }\end{array}$ & $\begin{array}{c}\text { Per } \\
\text { cen } \\
\text { tag } \\
\text { e }\end{array}$ & $\begin{array}{l}\text { Me } \\
\text { an }\end{array}$ & $\begin{array}{c}\text { The } \\
\text { Directio } \\
\text { n }\end{array}$ & $\begin{array}{c}\text { Dev } \\
\text { iati } \\
\text { on }\end{array}$ & $\begin{array}{c}\text { Chi } \\
\text { Squa } \\
\text { re }\end{array}$ \\
\hline 1 & $\begin{array}{l}\text { Some GCC countries } \\
\text { support extremism in } \\
\text { the Arab region }\end{array}$ & 64 & $\begin{array}{l}35 \\
\%\end{array}$ & 50 & $\begin{array}{l}27 \\
\%\end{array}$ & 31 & $\begin{array}{l}17 \\
\%\end{array}$ & 24 & $\begin{array}{l}13 \\
\%\end{array}$ & 15 & $\% 8$ & 3,67 & Neutral & 1,29 & 62,36 \\
\hline 2 & $\begin{array}{l}\text { GCC countries are } \\
\text { not united on } \\
\text { regional issues }\end{array}$ & 60 & $\begin{array}{l}33 \\
\%\end{array}$ & 57 & $\begin{array}{l}31 \\
\%\end{array}$ & 31 & $\begin{array}{l}17 \\
\%\end{array}$ & 19 & $\begin{array}{l}10 \\
\%\end{array}$ & 17 & $\% 9$ & 3,62 & Agree & 1,29 & 55 \\
\hline 3 & $\begin{array}{l}\text { Qatar has a political } \\
\text { vision that is } \\
\text { incompatible with the } \\
\text { rest of the GCC }\end{array}$ & 70 & $\begin{array}{l}38 \\
\%\end{array}$ & 51 & $\begin{array}{l}28 \\
\%\end{array}$ & 35 & $\begin{array}{l}19 \\
\%\end{array}$ & 17 & $\% 9$ & 11 & $\% 6$ & 3,83 & Agree & 1,21 & 88,65 \\
\hline
\end{tabular}




\begin{tabular}{|c|c|c|c|c|c|c|c|c|c|c|c|c|c|c|c|}
\hline & states & & & & & & & & & & & & & & \\
\hline 4 & $\begin{array}{l}\text { The Gulf crisis with } \\
\text { the State of Qatar } \\
\text { could open the doors } \\
\text { to foreign } \\
\text { interventions in the } \\
\text { region }\end{array}$ & 20 & $\begin{array}{l}11 \\
\%\end{array}$ & 42 & $\begin{array}{l}23 \\
\%\end{array}$ & 27 & $\begin{array}{l}15 \\
\%\end{array}$ & 57 & $\begin{array}{l}31 \\
\%\end{array}$ & 38 & $\begin{array}{l}21 \\
\%\end{array}$ & 2,72 & Disagree & 1,32 & 36,28 \\
\hline 5 & $\begin{array}{l}\text { The dispute between } \\
\text { the GCC states will } \\
\text { negatively affect their } \\
\text { defence capabilities }\end{array}$ & 9 & $\% 5$ & 22 & $\begin{array}{l}12 \\
\%\end{array}$ & 49 & $\begin{array}{l}27 \\
\%\end{array}$ & 65 & $\begin{array}{l}35 \\
\%\end{array}$ & 39 & $\begin{array}{l}21 \\
\%\end{array}$ & 2,44 & Disagree & 1,10 & 74,31 \\
\hline 6 & $\begin{array}{l}\text { The Gulf media were } \\
\text { neutral in their } \\
\text { reporting of events }\end{array}$ & 57 & $\begin{array}{l}31 \\
\%\end{array}$ & 53 & $\begin{array}{l}29 \\
\%\end{array}$ & 40 & $\begin{array}{l}22 \\
\%\end{array}$ & 19 & $\begin{array}{l}10 \\
\%\end{array}$ & 15 & $\% 8$ & 3,64 & Agree & 1,25 & 58,51 \\
\hline 7 & $\begin{array}{l}\text { The competition of } \\
\text { the GCC countries in } \\
\text { their foreign policies } \\
\text { is behind the crisis }\end{array}$ & 55 & $\begin{array}{l}30 \\
\%\end{array}$ & 47 & $\begin{array}{l}26 \\
\%\end{array}$ & 31 & $\begin{array}{l}17 \\
\%\end{array}$ & 34 & $\begin{array}{l}18 \\
\%\end{array}$ & 17 & $\% 9$ & 3,48 & Neutral & 1,33 & 38,11 \\
\hline 8 & $\begin{array}{l}\text { The intervention of } \\
\text { the Arab coalition in } \\
\text { Yemen threatens the } \\
\text { unity of the Council } \\
\text { The relationship of } \\
\text { some GCC states } \\
\text { with Iran could } \\
\text { create a schism } \\
\text { within the council }\end{array}$ & 42 & $\begin{array}{l}23 \\
\%\end{array}$ & 70 & $\begin{array}{l}38 \\
\%\end{array}$ & 23 & $\begin{array}{l}12 \\
\%\end{array}$ & 35 & $\begin{array}{l}19 \\
\%\end{array}$ & 14 & $\% 8$ & 3,33 & Agree & 1,23 & 73,04 \\
\hline
\end{tabular}

\begin{tabular}{|c|c|c|c|c|c|c|c|c|c|c|c|c|c|c|c|}
\hline $\begin{array}{l}\mathbf{N} \\
\mathbf{0}\end{array}$ & $\begin{array}{c}\text { Emotional } \\
\text { Dimensions }\end{array}$ & $\begin{array}{c}\text { Str } \\
\text { ong } \\
\text { ly } \\
\text { Agr } \\
\text { ee }\end{array}$ & $\begin{array}{c}\text { Per } \\
\text { cen } \\
\text { tag } \\
\text { e }\end{array}$ & $\begin{array}{c}\text { Agr } \\
\text { ee }\end{array}$ & $\begin{array}{l}\text { Per } \\
\text { cen } \\
\text { tag } \\
\text { e }\end{array}$ & $\begin{array}{l}\text { Neu } \\
\text { tral }\end{array}$ & $\begin{array}{l}\text { Per } \\
\text { cen } \\
\text { tag } \\
\text { e }\end{array}$ & $\begin{array}{c}\text { Dis } \\
\text { agr } \\
\text { ee }\end{array}$ & $\begin{array}{l}\text { Per } \\
\text { cen } \\
\text { tag } \\
\text { e }\end{array}$ & $\begin{array}{c}\text { Str } \\
\text { ong } \\
\text { ly } \\
\text { Dis } \\
\text { agr } \\
\text { ee }\end{array}$ & $\begin{array}{l}\text { Per } \\
\text { cen } \\
\text { tag } \\
\text { e }\end{array}$ & $\begin{array}{c}\text { Me } \\
\text { an }\end{array}$ & $\begin{array}{c}\text { The } \\
\text { Directio } \\
\text { n }\end{array}$ & $\begin{array}{c}\text { Dev } \\
\text { iati } \\
\text { on }\end{array}$ & $\begin{array}{c}\text { Chi } \\
\text { Squa } \\
\text { re }\end{array}$ \\
\hline 1 & $\begin{array}{l}\text { I have an optimistic } \\
\text { view that the } \\
\text { members of the } \\
\text { Council will } \\
\text { overcome their } \\
\text { differences soon }\end{array}$ & 13 & $\% 7$ & 34 & $\begin{array}{l}18 \\
\%\end{array}$ & 47 & $\begin{array}{l}26 \\
\%\end{array}$ & 64 & $\begin{array}{l}39 \\
\%\end{array}$ & 26 & $\begin{array}{l}14 \\
\%\end{array}$ & 2,70 & Disagree & 1,14 & 60,61 \\
\hline 2 & $\begin{array}{l}\text { I am concerned about } \\
\text { the stability of the } \\
\text { GCC countries after } \\
\text { the Qatar crisis }\end{array}$ & 25 & $\begin{array}{l}14 \\
\%\end{array}$ & 59 & $\begin{array}{l}32 \\
\%\end{array}$ & 34 & $\begin{array}{l}18 \\
\%\end{array}$ & 46 & $\begin{array}{l}25 \\
\%\end{array}$ & 20 & $\begin{array}{l}11 \\
\%\end{array}$ & 3,13 & Neutral & 1,24 & 42,77 \\
\hline 3 & $\begin{array}{l}\text { The inclusion of new } \\
\text { countries in the } \\
\text { council may threaten } \\
\text { its unity }\end{array}$ & 16 & $\% 9$ & 37 & $\begin{array}{l}20 \\
\%\end{array}$ & 48 & $\begin{array}{l}26 \\
\%\end{array}$ & 53 & $\begin{array}{l}29 \\
\%\end{array}$ & 30 & $\begin{array}{l}16 \\
\%\end{array}$ & 2,76 & Disagree & 1.20 & 38,04 \\
\hline
\end{tabular}




\begin{tabular}{|c|c|c|c|c|c|c|c|c|c|c|c|c|c|c|c|}
\hline 4 & $\begin{array}{l}\text { The crisis between } \\
\text { the GCC countries } \\
\text { will affect the volume } \\
\text { of investments in } \\
\text { those countries }\end{array}$ & 34 & $\begin{array}{l}18 \\
\%\end{array}$ & 73 & $\begin{array}{l}40 \\
\%\end{array}$ & 36 & $\begin{array}{l}20 \\
\%\end{array}$ & 31 & $\begin{array}{l}17 \\
\%\end{array}$ & 10 & $\% 5$ & 3,49 & Neutral & 1,14 & 78,72 \\
\hline 5 & $\begin{array}{l}\text { The reasons for the } \\
\text { dispute between the } \\
\text { GCC states are } \\
\text { intellectual, religious, } \\
\text { and economic rather } \\
\text { than political }\end{array}$ & 18 & $\begin{array}{l}10 \\
\%\end{array}$ & 32 & $\begin{array}{l}17 \\
\%\end{array}$ & 41 & $\begin{array}{l}22 \\
\%\end{array}$ & 71 & $\begin{array}{l}39 \\
\%\end{array}$ & 22 & $\begin{array}{l}12 \\
\%\end{array}$ & 2,74 & Disagree & 1,17 & 68,99 \\
\hline 6 & $\begin{array}{l}\text { The GCC states have } \\
\text { a common vision to } \\
\text { preserve the unity of } \\
\text { the council }\end{array}$ & 16 & $\% 9$ & 28 & $\begin{array}{l}15 \\
\%\end{array}$ & 50 & $\begin{array}{l}27 \\
\%\end{array}$ & 59 & $\begin{array}{l}32 \\
\%\end{array}$ & 31 & $\begin{array}{l}17 \\
\%\end{array}$ & 2,67 & Disagree & 1,18 & 49,66 \\
\hline 7 & $\begin{array}{l}\text { The Gulf } \\
\text { Cooperation Council } \\
\text { is a model for a } \\
\text { successful Arab } \\
\text { project }\end{array}$ & 24 & $\begin{array}{l}13 \\
\%\end{array}$ & 36 & $\begin{array}{l}20 \\
\%\end{array}$ & 71 & $\begin{array}{l}39 \\
\%\end{array}$ & 37 & $\begin{array}{l}29 \\
\%\end{array}$ & 16 & $\% 9$ & 3,08 & Neutral & 1,13 & 68,45 \\
\hline
\end{tabular}

It is clear from the respondents' answers to the first phrase of the cognitive dimensions (the GCC unity faces a crucial challenge) that (33) of the sample members agreed strongly, which constitutes a percentage of (18\%), while (47) of them agreed on the statement, which constitutes ( $26 \%$ ) of the respondents, while the position of neutrality came at (42) recurring and with a percentage of $(23 \%)$, while (37) respondents rejected the phrase, which constitutes $(20 \%)$ of the respondents, and (25) respondents strongly refused to agree with the phrase with a percentage of $(14 \%)$, while the value of the chi-square was (18.38), which formed a neutral trend among scholars for the phrase, which indicates the convergence of the percentage of those who agree and disagree, and this reflects the size of the division among the sample members in their vision of the fateful challenge that may face the unity of GCC countries.

However, (47) respondents strongly agreed that the countries of the Gulf Cooperation Council are not unified regarding regional issues, which constitutes $(26 \%)$ of the total of the two statistics, while (41) respondents agreed with the statement with a percentage of $(22 \%)$, while the position was neutral for ( 33) respondents, with a percentage of $(18 \%)$, and (34) refused to agree with the phrase, with a percentage of (18\%), and (29) of the respondents strongly refused to agree with the phrase, which constitutes a percentage $(16 \%)$ of the total respondents, while it reached the value of chi-square (15.68), which is a neutral trend.
This result indicates the same direction in the respondents' view of their vision for the future of the unity of the Gulf Cooperation Council countries.

Twenty-two respondents strongly agreed to agree with the phrase that the causes of the Gulf dispute with Qatar go back to the so-called white coup in 1995, while (41) respondents, which constituted $22 \%$ of the respondents, agreed with the phrase, and (21) respondents were neutral in the agreement with the phrase at a percentage of (11\%), (42) respondents refused to agree with the phrase with a percentage of (23\%), while (58) respondents strongly refused to agree with the phrase, which constitutes a percentage estimated at $(32 \%)$ of the total respondents. Chi-square value was (41.28).

This indicates that there is a trend that reflects a state of rejection and disagreement with the phrase among the respondents, although there is a trend in some literature that the roots of this dispute go back to the white coup incident that occurred in Qatar in 1995, so there is a view among many scholars and analysts politicians are heading in the same direction.

The respondents agreed strongly with that the Qatari crisis will affect in the future the project of political and economic integration of the GCC states with (38) recurrences and with a percentage of $(21 \%)$, while (51) respondents agreed with a percentage of (28\%) and (19) respondents indicated that their impartiality in agreeing with the statement, which constitutes $(16 \%)$ of the total sample, and (50) respondents did not agree with the 
statement, and it is related to $(27 \%)$ of the total respondents, while it strongly rejected (26) respondents and $(14 \%)$ of the respondents. The proportion of respondents, which made the general trend neutral among the respondents, while the value of chi-square was (36.15).

This result indicates a state of division among the respondents on the repercussions of the future crisis on the project of political and economic integration of the GCC countries, despite the relative increase in the number of respondents who agreed with the statement compared to the number of those who did not agree.

The result of the answer to the phrase "I derive my information about the Gulf crisis with Qatar from social networking sites" indicates a strong agreement (40) respondents, with a percentage of (22\%), and (52) respondents agreed with them, and the position of neutrality came to constitute (31) recurrence, with a percentage of (17). \%) and rejected this by (31) respondents with a percentage estimated at (17\%), while (30) respondents strongly refused to agree with the statement, which reflected a general neutral trend, while the value of the chi-square came to register (20.74).

These results, despite their general, neutral trend, indicate that not a small number of respondents derive their information about the Gulf crisis with Qatar from social networking sites, taking into account the percentage of neutrals whose dependence on these sites may vary, which is an important source of access information and the formation or reinforcement of a mental image of the other, especially that the respondents are from the academic elite, which is known for their accuracy and scrutiny of the information they receive from different sources of the media, and this result indirectly indicates a decrease in the percentage of dependence on the traditional audio-visual and print media, as the results of the respondents who draw their information from these sources reaches approximately one third of the respondents.

In the same way, which emerged from the results of the answer to the previous question, the results of the answer came to the possibility of the respondents to derive their information about the Gulf crisis from television, which until recently was the first source for obtaining information, except that (37) respondents agreed strongly and (50) iterations were recorded for the state of agreement and in percentages they reached $(20 \%)$ and (27\%), respectively, which are slightly less than the two levels cleared by the results of the previous question for the same two levels, while the neutrals reached (54), or $(29 \%)$ of the respondents, while the numbers of those who disagreed reached (22) and (21) with a percentage of $(12 \%)$ and $(11 \%)$, respectively, which resulted in a positive trend as well, and the value of the chi-square was (40.48).

These results indicate an important fact represented in the low percentage of dependence on television as a first means that for several decades dominated the mind of the recipient, to replace it with social networking sites despite the importance of television, and this was reflected in the results of the respondents' answers regarding their limited relative agreement with the question posed.

Large percentages of the respondents refused to agree with the statement, "I derive my information about the crisis from the radio", as the rejection case was recorded with (73) recurrences and the rejection strongly for (38) respondents with percentages of $(40 \%)$ and $(21 \%)$, respectively, which is the percentage of a task that exceeded more than half of the sample members, while the case of agreement was recorded strongly and agreement (18) and (21) recurrence with a percentage of (15\%) and $(11 \%)$, respectively, which is a weak percentage if compared to the rest of the media, and this formed a trend year, refusing to agree with the presented statement, and the value of the chi-square came to be (73.72).

These data seem realistic to a significant degree after the dominance of social networking sites and then television as sources approved by the recipients.

However, (23) respondents strongly agreed with the statement "I derive my information about the crisis from newspapers and publications", which constitutes (13\%), while (32) agreed with it at a percentage of $(17 \%)$, and the highest percentage of the neutral category came with (64) recurring, which formed a percentage estimated at $(35 \%)$ of the total respondents, and (51) respondents did not agree with it, with a percentage of (28\%), and (14) respondents did not agree strongly with a percentage of $(8 \%)$, while the value of the chi-square came to be (65.34) in a general direction 'neutral'.

Although the research sample was from the academic elite, the percentage of their dependence on newspapers to obtain information about the crisis appears to be very limited, and perhaps this does not seem strange if we accept the development taking place in social networking sites on the websites of newspapers, whose numbers began to decline and their distribution became limited to a certain extent, readers are directed to the means closest to them, such as mobile phones, which can summarize the world with its capabilities, applications and websites. This result indicates a state of transformation in the sources of information obtained for the respondents.

The respondents strongly agreed with (17) recurrences and with a percentage of $(9 \%)$ with the statement that "the Gulf Cooperation Council countries support the unity of Iraq 
and its political system", while (44) recursions agreed with it at a percentage of $(24 \%)$ came neutrality to be represented by (29) respondents. At a percentage of (16\%), while it contradicted it (40) iterations $(22 \%)$ and strongly rejected it (54) iterations, which constitutes (29\%) of the number of respondents.

This result indicates a mental image of the academic elite that seems negative about the role played by the Gulf Cooperation Council countries towards the unity of Iraq and its political system. The relationships between US administration and Iraq result repercussions on the level of the relationship between the two parties, especially after the development of the size of the relationship between the Iraqi governments and Iran, and the emergence of many disputes and accusations about the relationship of some GCC states with supporting extremists in Iraq.

Also, (11) respondents agreed strongly with the statement that "the council can expand to include other Gulf countries such as Iraq and Yemen", with a percentage of $(6 \%)$, and 28 respondents agreed with it with a percentage of $(15 \%)$ respondents, while the percentage of neutrals $(12 \%)$ and the number of iterations amounted to (22) iterations, while (52) respondents refused to agree with it with a percentage of (28\%) and strongly rejected (71) respondents, which constitutes a percentage estimated at (39\%), and the value of chi-square was (88.58). In a general (rejecting) direction for the phrase.

These results indicate a clear case of disagreement with the story, even though countries such as Iraq and Yemen have common borders with the GCC countries, and they also have ports on the coast of the Arabian Gulf, which allows them to have similar or absolute conditions to the Gulf reality. This may be due to the foreign policy adopted by the GCC states and their stable economic reality compared to Iraq and Yemen, which are witnessing continuous conflicts and a state of instability and have an economic reality that is weak or inferior to that of the GCC states.

However, (33) respondents with a percentage of (18\%) agreed strongly with the statement that "the emergence of young leaders in the GCC countries may contribute to the end of the council", and (70) respondents agreed with it with a percentage estimated at (38), while the result of neutrality came to be recorded (32) At a percentage of $(17 \%),(28)$ repeatedly refused to agree with the statement, and strongly rejected (21) repeatedly, in a percentage of $(15 \%)$ and $(11 \%)$, respectively, and the value of the chisquare was (58.31) in a general (neutral) direction.

This result indicates a clear increase in the percentage of those who agree with the text of the phrase questioned about it, and perhaps this is due to the role played by the Saudi Crown Prince Muhammad bin Salman and the Emir of the State of Qatar Sheikh Tamim bin Hamad, who are considered among the young leaders, and whose political role in their countries is known, which may leads to expose the GCC states to several challenges because of the boldness in their decisions, which puts the GCC states in front of a reality of crises.

However, (47) respondents agreed strongly, and (45) respondents agreed as well, with a percentage of (26\%) and $(24 \%)$, respectively, while neutrality was repeated (33) recurrences with a percentage of (18\%) and refused to agree with the phrase (39) respondents with a percentage of $(21 \%)$ and strongly rejected (20) respondents with a percentage of $(11 \%)$ and the value of chi-square was (24.73) and the trend was recorded 'neutral'.

This result indicates a view of the respondents that does not tend to agree or reject the statement, and this result may seem logical to a large extent as long as the internal challenge is the most prominent factor in the dispute, even if it is represented in the foreign policies of the GCC states and the lack of agreement on the unity of their direction.

Some respondents strongly agreed with the statement that "the tense relationship between the United States of America and Iran will negatively affect the GCC countries" (76) respondents, at a percentage of (41\%) repeatedly, and also agreed with it (45) respondents, accounting for $25 \%$ of the total respondents, and repeated neutrality (35). ) repeatedly with a percentage of up to $(19 \%)$ in refusing to agree with the phrase (17) repeatedly and strongly rejecting (11) respondents with percentages of $(9 \%)$ and $(11 \%)$, respectively, and the value of chisquare was recorded (88.65) in a general direction 'OK' with the phrase understood.

This result indicates a worried view of the respondents' view of the effects resulting from the tensions and the tense relationship between the United States of America and Iran, given that both countries have a size of influence and power in the Arab Gulf region. The threat to prevent the export of oil, which is the most prominent cause of the conflict and the most important reason for the conflict, in addition to the strategic location of the countries in the region, and the Strait of Hormuz, which Iran has threatened several times to close to international shipping, is a reason added to this tension, especially after the United States confirmed its ability to secure international navigation regarding Iranian threats.

The respondents refused to agree with the statement that "the crisis between the GCC states has a media dimension more than it is political", as it rejected (65) iterations, which constitutes $(35 \%)$ of the respondents, while it strongly rejected (42) iterations, which is $(23 \%)$. Some of the respondents agreed with the statement, while a limited 
number of respondents agreed with it strongly, estimated at (9) iterations, with a percentage estimated at $(5 \%)$ of the total respondents, while (41) repeatedly agreed, which constitutes $(22 \%)$ of the total respondents. The result of neutrality was repeated (27) recurring with a percentage of $(15 \%)$, and the value of chi-square was recorded (36.28) in a general direction refusing to agree with the phrase.

This result clearly indicates the respondents' view of the crisis as having a political depth that is not limited to the media exchange that occurs through the audio, visual and print media of the crisis countries, which own many satellite channels through which they broadcast their vision to a wide and large audience. Satellite channels that record a high rate of follow-up from recipients, while the rest of the GCC countries have many satellite channels such as Al Arabiya, Al Hadath and Abu Dhabi, which are satellite channels that have a high viewership, which can be considered the mouthpiece of some of the GCC countries that are living the reality of the crisis with its neighbor Qatar.

In a second dimension which is the behavioral dimension, the results of the respondents came to record a discrepancy in the response to the expressions of the scale. The respondents agreed with the phrase "some of the GCC countries support extremism in the Arab region" in its general framework, after it was agreed strongly with (64) respondents with a percentage of (35) \%) of the respondents, and (50) respondents agreed with a percentage of $(27 \%)$ of the total respondents, and the percentage of neutrality in the respondents' responses was estimated at (17\%) after (31) recurrences, and (24) respondents rejected it with a rate of $(13 \%)$ ) of the respondents, while (15) respondents strongly rejected it, at a percentage of $(8 \%)$ of the total respondents. The value of chi-square was (62.36).

This result indicates a mental image among the respondents that sees in some countries of the Cooperation Council that it supports extremism in the Arab region, and this was among the reasons for the Gulf dispute, and it constitutes a point of agreement with the Iraqi public, which points the finger of accusation at Qatar in its direct sponsorship or indirect to some extremist parties, an example of this relationship with extremists is the incident of kidnapping Qatari fishermen and the arrival of large sums of money to Baghdad International Airport via a Qatari plane that was seized by the Iraqi government and deposited in the Central Bank of Iraq as seized money, which was later said by the Qatari opponent Sultan bin Suhaim "that Qatar paid one billion dollars" to release the fishermen, and many political analysts have interpreted that deal as sponsoring extremist parties, and accusations were directed from time to time to Qatar in its support with funds for armed groups fighting in Iraq.

The respondents agreed strongly with the statement that "Qatar has a political vision that is incompatible with the rest of the GCC countries", at a percentage of (60) recurring and a percentage of $(33 \%)$, and 57 respondents agreed with it, with a percentage of $(31 \%)$, and neutrality was recorded (31) repeatedly with a percentage of $(17 \%)$ and rejection of the agreement (19) respondents with a percentage of (10) and strong rejection of (17) respondents with a percentage of $(9 \%)$, and the value of the chi-square reached (55) in a general direction in agreement with the phrase .

It is possible to conclude from that result that one of the causes of the Gulf dispute, which has reached the level of crisis, is due in one of its causes to the Qatari political vision that is incompatible with the rest of the GCC countries, in reference to the existing difference in the structure and different political orientation of Qatar, and this different vision was clear in the relationship between Qatar and the GCC states, which were witnessing from time to time interactions are clearly visible.

However, (70) respondents agreed strongly with the statement that "the Gulf crisis with the State of Qatar could open the doors for external interventions in the region" with a percentage estimated at (38\%), and (51) respondents agreed with it, with a percentage of $(28 \%)$ of the total respondents, while it was scored as neutral. (35) repeatedly with a percentage of $(19 \%)$ and refused to agree with (17) respondents with a percentage of $(9 \%)$ and strongly rejected (11) respondents with a percentage of $(6 \%)$, and the value of the chi-square reached (88.65), while the general trend was to see the respondents consistent with the phrase questioned.

It is possible to conclude from the result that the respondents see the Qatari crisis as an area for external intervention in the region. This result seems clear and consistent with the nature of all crises that cause confusion in relations and cause a state of weakness in any entity that afflicts it, which requires confronting and managing it to weaken its risks.

The results of the respondents' answers to the statement that "the dispute is in the hands of the GCC states will negatively affect their defence capabilities" were recorded. (20) were highly questioned, and (42) agreed with them, with a percentage of $(11 \%)$ and $(32 \%)$ respectively, while the neutrality was repeated in (27) recurring with a percentage of $(15 \%)$, while it was rejected by (57) with a percentage of $(31 \%)$, and it was strongly rejected by (38) respondents with a percentage of $(21 \%)$. While the value 
of chi-square was (36.28), and the general trend was refusing to agree with the statement.

From this result, it becomes clear that the respondents' vision shares to a large extent their view that the Gulf dispute will not affect the defense capabilities of the GCC countries, especially since the defence spending of these countries is very large, and high budgets are allocated to it, until it was classified as the highest purchase of arms in the region. These countries are also working to obtain the latest and most advanced weapons from international companies that produce them, especially the United States of America.

The respondents did not agree with the statement that "the Gulf media were impartial in their reporting of the events", as it was strongly rejected by (39) respondents and also rejected by (65) respondents with a percentage of $(21 \%)$ and $(35 \%)$ respectively, while they agreed with them. A very limited number of (9) recurrences, with a percentage of $(5 \%)$, as agreed with (22) respondents, at a percentage of $(12 \%)$, and neutrality was repeated in (49) with a percentage of $(27 \%)$, while the value of chi-square was recorded ( 74.31).

These results indicate that the Gulf media are not impartial in their reporting of events, which is a result that may seem natural as long as these media follow the agendas of the institutions or countries that support them, so they do not deviate from the directions of their supporters, and the media treatment of these media makes them present certain contents without others, which it may contribute to highlighting issues and events in a manner commensurate with the vision of the channel and the institution and from a certain angle, not from different angles.

Regarding the statement that "the competition of the GCC states in their foreign policies is behind the crisis", some agreed with it strongly (57) recurringly with a percentage of $(31 \%)$, and agreed with it (53) and at a percentage of $(29 \%)$, and the neutrality was recorded (40) recurring with a percentage of a percentage amounted to (22\%), while refusing to agree with it (19) at a percentage of (10\%) and strongly rejecting it (15) repeatedly at a percentage of $(8 \%)$ and the value of the chi-square was (58.51), and the general trend of the respondents was 'I agree' with the phrase questioned about it.

It is possible to conclude from this result that the mental image of the GCC states among the respondents has recorded a state of competition between the GCC states in their foreign policy, and this competition is moving towards turning into a state of conflict as it has shifted from the role of competition to a reality of crisis and may develop in the future to witness a conflict between its states in the region.
The respondents agreed strongly with the phrase "the intervention of the Arab coalition in Yemen threatens the unity of the Council" with a number of (55) recurrences and a percentage of (30\%), and also agreed with it (47) repeatedly and with a percentage of (26\%), while neutrality came in responses to score (31) Frequently and at a percentage of $(17 \%)$ of the total respondents, and the respondents refused to agree with the phrase (34) repeatedly and at a percentage of (18\%) and strongly rejected it (17) repeatedly and at a percentage of (9\%), and the value of chi-square was (38.11), while the direction was recorded generally of the respondents neutrality position on the phrase.

Although the general trend of the respondents was neutral, only a relatively large proportion of the number of respondents recorded their agreement with the statement, and this indicates that the Arab intervention in Yemen may threaten the unity of the Council, especially with the presence of discrepancy between the GCC states regarding the Arab intervention in Yemen between supporter and opponent, and this discrepancy may threaten the unity of the GCC states.

The respondents agreed strongly with the statement that "the relationship of some GCC countries with Iran could create a schism within the council" with a number of (42) recurrences, and (70) respondents agreed with it with a percentage of $(38 \%)$ of the total respondents, while the number of neutrals was (23). Repeatedly with a percentage of $(12 \%)$, and the agreement was rejected by (35) respondents as well as strongly rejected by (14) repeatedly with percentages amounting to (19\%) and (8\%), respectively, while the value of the chi-square was (73.04) and the general trend of the respondents' answers was 'agreement' with the phrase.

It is possible to conclude from this result that the relationship with Iran constitutes one of the causes of disagreement and creation of schism between the Gulf states. This result records the relationship specifically the relationship between Qatar and Iran, which some of the GCC states consider to be in violation of the directions of the Council, which is linked by a single policy that must be adhered to by all the GCC states. The crisis between the GCC states has proven the validity of these results, as Qatar resorted on more than one occasion to present Iran as the party that could contribute to helping it face the conditions of stopping commercial and political dealings between the GCC states and Qatar, while Iran opened its borders and airspace to the movement of people and goods coming from and to Qatar, and this is what Qatar has interpreted as an economic blockade by the GCC countries 
aimed at forcibly subordinating the Qatari foreign policy to the policy of the Gulf Cooperation Council.

The respondents' answers came to the third dimension of the scale form which is the emotional dimension, as shown below:

The respondents rejected the statement "I have an optimistic view that the members of the council will overcome their internal differences soon", as the results of the answers to the statement showed that only (13) recursions strongly agreed with it, with a percentage of (7\%) of the total respondents, and (34) respondents also agreed with it. At a percentage of (18\%), and the result of neutrality was apparent in (47) recurrences, which is a percentage of $(26 \%)$, except that (64) iterations recorded their rejection of the phrase and (26) recurrences strongly rejected the agreement, which constituted a percentage of $(39 \%)$. and (14\%), respectively, while the value of the chisquare was (60.61) in a general direction satisfied to agree with the statement.

It is possible to conclude from these answers that the respondents were not optimistic about the possibility of the GCC states overcoming their inter-related differences, which may allow the continuation of disagreements between the GCC states, and this suggests the continuation of the crisis and the inability to overcome it in the short term as long as the GCC states did not go beyond the limits of their inter-related differences.

The position of neutrality came to be noted as a result of the respondents' answers to the statement "I am concerned about the stability of the GCC countries after the Qatari crisis", as some agreed strongly with the statement (25) repeatedly, as well as (59) repeatedly, with percentages amounting to (14\%) and (32\%) on the respectively, while the position of neutrality was repeated (34) repeatedly at a percentage of (18\%), while it was rejected (46) repeatedly and strongly rejected (20) repeatedly with a percentage of $(11 \%)$ of the total respondents. The value of the chi-square came to register (42.77).

These results indicate a seemingly realistic view by the respondents of the GCC states, and despite going through the stages of an internal crisis, stability is still the dominant feature in its structure as it has not yet reached the level of a military clash, and that the crisis is still within the limits of the political aspects and has not emerged from it, as it enjoys clear economic stability, which in turn is reflected on its people, which dispels the anxiety that may be felt by the observer of that crisis.

The respondents refused to agree with the statement that "the inclusion of new countries in the council's membership may threaten its unity", a limited number of respondents, estimated at (16) recurringly, and at an estimated percentage of (9\%), agreed with it strongly (37) and at a percentage of (20). \%) of the total respondents, and the position of neutrality was recorded (48) repeatedly at a percentage of (26\%) and refused to agree with it (53) repeatedly by $(29 \%)$ of the respondents, while it was strongly rejected (30) repeatedly at a percentage of (16\%), and the value of Chi-square is scored (38.04) in the negative direction of the story.

It is possible to conclude from these answers that the inclusion of new countries such as Iraq and Yemen in the membership of the Council does not constitute a threat to its unity. These countries enjoy it while the state of instability is still evident in Iraq and Yemen, which may contribute to creating or reflecting instability on the GCC states in the event they take the decision to include the two new states in its membership.

The respondents agreed with the phrase "the crisis between the GCC countries will affect the volume of investments in those countries". After it was agreed strongly (34) repeatedly with a percentage of (18\%), and (73) respondents agreed with it with a percentage of (40\%) of the total respondents, while neutrality came to score (36) repeatedly at $(20 \%)$ and refused to agree with the phrase (31) recurs at a percentage of $(17 \%)$ and it was strongly rejected by (10) recurrences with a rate of $(5 \%)$ of the total respondents.

This result indicates the limited cases of disagreement or rejection of the phrase, as a good percentage of the respondents agreed with the phrase, for each crisis has its repercussions on a certain aspect of life, especially the investment sector, which requires a stable investment environment for the companies investing in it to operate away from turmoil or crises. Despite that answer, which bears an emotional nature from the respondents, we have not seen the effects or repercussions of the crisis on the volume or sustainability of investment in the Gulf Cooperation Council countries, except for threats and fears in some companies operating in Qatar over the implementation of projects for the organization of the World Cup will be organized by the State of Qatar in 2022, but it quickly faded after a while.

The respondents refused to agree with the phrase "the reasons for the dispute between the GCC states is intellectual, religious and economic more than political", as (18) respondents agreed with it strongly, with a percentage of $(10 \%)$, and (32) respondents agreed with it at a percentage of $(17 \%)$. Of the respondents, neutrality came to form the answers of (41) respondents with a percentage of $(22 \%)$, while (71) respondents rejected it and also strongly rejected (22) respondents with 
percentages of $(39 \%)$ and $(12 \%)$, and the value of chisquare was recorded ( 68.99 ).

These results indicate that the nature of the crisis between the GCC states does not appear to be very deep, but rather is political. In political science, politics is called the art of the possible. Therefore, reaching solutions to the crisis is natural and consistent with the size of the dispute, because the ties and relations on which the GCC states meet are greater than the size of the crisis that the GCC states. The respondents see it as not intellectual, religious or economic, and here it can be described as a crisis that is not fundamental, but superficial, and it can be overcome by peaceful and political means.

The respondents refused to agree with that "the GCC states have a common vision to preserve the unity of the council". A limited number of respondents, estimated at (16) recurs, strongly agreed with the statement, as agreed with it (28) recurring, at a percentage of $(15 \%)$ of the total respondents, and the result was Neutrality was represented by $(50)$ recurrences at a percentage of $(27 \%)$, while the agreement was rejected (59) recurringly at a percentage of $(32 \%)$ and strongly rejected by (31) recurrence at a percentage of $(17 \%)$, and the value of the chi-square was recorded (49.66).

These results indicate that the respondents have an image of the GCC states that they do not have a common and unified vision to preserve the unity of the Council, and perhaps this is one of the main reasons for the dispute or crisis between the GCC states, especially since some of the respondents' answers look at the conflict that it did not rise to the level of religious or economic conflicts or the deep intellectual, and that some of the GCC countries have a vision towards issues and events that may not match the visions of the rest of the GCC countries, and thus they need to coordinate their visions and positions more in order to prevent getting into future crises.

With regard to the phrase "the Gulf Cooperation Council represents a model for a successful Arab project", the respondents' answers varied between those who agreed with them strongly (24) recursions and $(13 \%)$ of the total respondents, as agreed with them (36) by (20\%), while the state of neutrality was recorded ( 71) repeatedly and at a percentage of $(39 \%)$, which is the highest percentage in the respondents' answers. Some refused to agree with them (37) at a percentage of (29\%) and strongly rejected it (16) at a percentage of $(9 \%)$, and the value of the chi-square was (68.45), The general trend of the respondents' answers was 'neutral'.

These results indicate a contradiction in the opinions of the respondents between those who agree with those who see that the experience of the Gulf Cooperation Council is a model for the successful Arab project, and between a vision that differs with it and does not accept this vision. Although, it witnessed experiments and political gatherings, they soon faded and disappeared after facing a number of challenges and crises.

Finally, it must be pointed out that the neutral trend shown by some of the results of the research does not refer to the neutrality in the position of the statements included in the research as much as it refers to a state of division of opinion between those who disagree and agree. It also indicates a limited agreement between the respondents for a rejection or agreed direction with some paragraphs.

\section{CONCLUSION}

In light of the respondents' answers, it has been concluded the following:

1- It turns out that those results, which were reflected in the respondents' answers, can provide clear and explicit answers about the objectives of the research. Qatar through answers generated by questions (1-2-4-14), as well as questions in the cognitive dimension (2-11) and (2-6-8) of the behavioral dimension on the second goal, which is to reach the causes of the Qatari crisis according to the vision of the Iraqi academic elite, questions (5-6-7-8) were also referred to the third objective of the research, which is to identify the areas from which the respondents derive their information about the Qatari crisis, and paragraphs (4-1011-12-13) from the cognitive dimension and (3-4) from the behavioral dimension and (4) from the emotional dimension on the fourth research objective, which is to identify the future of the Qatari crisis on the GCC countries in the eyes of the Iraqi academic elite, and the paragraphs (3-4-7-8) were postponed from the behavioral dimension on the fifth research objective, which is the repercussions of the Qatari crisis on the GCC countries and the region in the eyes of the Iraqi academic elite, and about the sixth goal of identifying any possible changes to the image of the GCC states among the Iraqi academic elite, most of the paragraphs can answer because they provide a clear vision of the mental image of the Gulf Cooperation Council countries after the Qatari crisis and the developments that may be witnessed.

2- Although the respondents were divided about their vision of the future of the Gulf Cooperation Council, they agreed that the GCC countries do not have a common vision to preserve the unity of the Council, and the emergence of young leaders with an influence in some of the GCC countries is one of the factors that threaten this entity, and the relationship. The convulsive relationship between the United States and Iran will negatively affect the GCC countries, and the relationship of some countries 
with Iran may allow the creation of a rift in the ranks of the Council, especially with both countries standing by one side of the crisis against the other, and the respondents' answers came to confirm this proposition after they agreed with the phrase "The Gulf crisis with the State of Qatar could open the doors for foreign interventions in the region."

3 - There is a negative mental image among the academic elite about the role played by the Gulf Cooperation Council countries towards the unity of Iraq, and the possibility of accepting it as a new member to be added to the GCC countries due to Iraqi invasion to Kuwait in 1990.

4- There is a mental image of the academic elite that sees that the crisis between the two parties is of a political nature more than it is informational, but its causes do not rise to the level of intellectual, religious or economic disputes or crises, which are usually characterized by depth and strong influence and repercussions.

5- The results of the analysis of the respondents' answers showed a negative mental image of the way the Gulf media dealt with aspects of the crisis, as these media were not neutral in their transmission of events, although social media was the first source of information received by the respondents, followed by television. The second, then the reading media ranked third, and the radio had no significant role in this aspect.

6- The results of the study also reflected a negative view of the possibility of the GCC countries to overcome their differences soon, and this is reinforced by their vision that is compatible with the incompatibility of the Qatari political vision with the rest of the GCC countries.

\section{RECOMMENDATIONS}

In order to reach positive and fruitful data from the research results, some recommendations have been made as the following:

1 - The Arabian Gulf countries present themselves to the masses in a new positive way, according to scientific planning and extensive studies of the nature of the mental image.

2- The Gulf countries should sponsor the organization of a series of studies on their mental image of the other, under the auspices of students of science in universities in order to study the cases of progress and development in the image.

3- The Gulf media should deal with the news material on the issue of the crisis between the GCC states according to the theory of social responsibility, and with high professionalism. This will contribute to changing the negative mental image about it into a positive one.

4- The necessity of the GCC states to present their political visions from each other in a way that will win the different masses, provided that they show signs of goodwill towards the other, far from withdrawing from attempts to win over the masses of their countries only.

\section{REFERENCES}

[1] Abdul Mohsen Lafi Al-Shammari, A. M. (2021).The Cooperation Council for the Arab States of the Gulf and the Challenge of Unity(Master's thesis) (K. Ethar, Trans.). Oman : Middle East University. (2011)

[2] Ajwa, A. (2021). Mental Image, and Public Relations(K. Ethar, Trans.). Cairo: World of Books. (1983)

[3] Al-Alkim, H. H.(2021). A Methodological Introduction to Crisis Management, Crisis Management Symposium(K. Ethar, Trans.). Officers Training Institute, Police College, Abu Dhabi, November 25-26, p. 3. (2000)

[4] Al-Sharqawi , F. \&Al-Qalini, S. (2021). The mental image formed by the Iraqi crisis among a sample of Egyptian society (K. Ethar, Trans.). Journal of Middle East Affairs. (7) , p.13. (2003)

[5] Al-Shatri, M. (2021). Television Advertising and its Role in Forming the Mental Image(K. Ethar, Trans.). Amman: Dar Osama (p.118). (2003)

[6] Barghash, B. (2021). Relations between the Cooperation Council for the Arab States of the Gulf and the European Union and their future prospects ( $\mathrm{Ph} . \mathrm{D}$ dissertation)(K. Ethar, Trans.). University of Baghdad. (2015)

[7] Barton, L. (2021). crisis in organization managing and communication in the Heat of chaes(K. Ethar, Trans.). USA (p.72). (1993)

[8] Bland, M. (2021). Communication out of a crisis(K. Ethar, Trans.). p.5,United kingdom: Palgrave Macmillan. (1998)

[9] Eleiwa, E. (2021). Crisis and Disaster Management, Scientific Solutions - Preventive Methods(K. Ethar, Trans.). Cairo: Dar Al-Ameen for Publishing and Distribution (p.80). (2003)

[10] Hawash, J. (2021). Crisis and Disaster Management is an Inevitable Necessity(K. Ethar, Trans.). In The Third Annual Conference on Crisis and Disaster Management (p. 270). (1998)

[11] Idris, M. A. (2021). Gulf Cooperation Council 1999 - 2000 The Gulf Strategic Report(K. Ethar, Trans.). Al Khaleej Newspaper. (2000)

[12] Jamal, D. (2021). The type of crisis and knowledge and its impact on determining future crisis management strategies, an exploratory study of the opinions of a sample of workers in the Al-Kadhimiya threshold(Ph.D dissertation)(K. Ethar, Trans.). Al-Mustansiriya University. (2010)

[13] John, R. (2021). Crisis Management: A Team Approach(K. Ethar, Trans.). New York: AMA Management Briefing (p.70). (1983)

[14] Marhoon, A. J. (2021).Gulf Security after the Cold War(K. Ethar, Trans.). Beirut:Dar Al-Nahar Publishing. (1997) 
[15] Meguid, Q. A. (2021). Crisis Communication and Crisis Management(K. Ethar, Trans.). p.85. Egypt : The New University House (2008)

[16] Mitsoff, L. \& Amagos, G. (2021). Managing Crisis Before They Happen (K. Ethar, Trans.). USA (p.41). (2001)

[17] Moreau, J. \& Reveret, D. (2021). Les Medias et La Communication dr Crise(K. Ethar, Trans.). Paris: STDI (p.31). (1997) 